\title{
AS ESCOLAS DE SAMBA E OS MOVIMENTOS NEGROS NOS ANOS 1960 UMA PÁGINA EM BRANCO NA HISTORIOGRAFIA BRASILEIRA
}

Guilherme José Motta Faria (UFF)

Os desfiles das agremiações cariocas nos anos 60 estavam inseridos no quadro de transformações culturais, revelando embates, lutas e disputas por espaços políticos e sociais. O objetivo desta comunicação é compreender como a temática da cultura negra era trabalhada pelas escolas no período. A partir das matérias do Jornal do Brasil, destaquei os enredos, sambas e as narrativas da história dos negros no Brasil. As escolas eram agremiações culturais sintonizadas nos debates da militância, embora consideradas manifestações folclóricas, sendo ignoradas pelas lideranças e organizações, o que se refletiu em importante lacuna na historiografia sobre o movimento negro brasileiro daquela década.

\section{ESCOLAS DE SAMBA; MOVIMENTOS NEGROS; REPRESENTAÇÕES SOCIAIS.}

FARIA, Guilherme José Motta. As escolas de samba e os movimentos negros nos anos 1960: uma página em branco na historiografia brasileira. Textos escolhidos de cultura e arte populares, Rio de Janeiro, v.11, n.2, p. 29-46, nov. 2014. 


\section{THE SAMBA SCHOOLS \\ AND THE BLACK MOVEMENT IN THE $1960 \mathrm{~S}$ \\ A BLANK PAGE IN BRAZILIAN HISTORIOGRAPHY}

Guilherme José Motta Faria (UFF)

The parades of Rio's samba schools in the 1960s were inserted as part of the cultural transformations, revealing clashes, fights and disputes by political and social spaces. The purpose of this article is to understand how the theme of black culture was dealt with by the samba schools during the period. The plots, sambas and narratives of the history of black people in Brazil were collected based on published pieces from Jornal do Brasil. Schools were cultural associations tuned into the debates of militancy, although seen as folklore groups, being ignored by the leaders and organizations, reflecting a major gap in the historiography of the Brazilian black movement in the 1960 s.

\section{SAMBA SCHOOLS, BLACK MOVEMENTS, SOCIAL REPRESENTATIONS}

FARIA, Guilherme José Motta. As escolas de samba e os movimentos negros nos anos 1960: uma página em branco na historiografia brasileira. Textos escolhidos de cultura e arte populares, Rio de Janeiro, v.11, n.2, p. 29-46, nov. 2014. 
O eixo central deste artigo é analisar a produção das escolas de samba como agremiações culturais, sintonizadas com as discussões dos movimentos negros, desde os anos 30 e 40, e efetivamente nas décadas de 1950 e 1960. A temática referente ao elemento negro esteve, em menor ou maior grau, presente nos desfiles das agremiações. Mesmo com essa evidência, as escolas de samba foram ignoradas pelas principais lideranças e organizações dos movimentos negros no Brasil. Vistas a princípio como manifestações folclóricas, as agremiações eram veículos importantes para a potencialização de uma narrativa politizada da história do negro no Brasil.

A história do carnaval carioca é campo que pode ser mais explorado visando à melhor compreensão da própria história política e cultural do Brasil. Esse campo atraiu a atenção de pesquisadores acadêmicos das áreas da antropologia e da sociologia desde os anos 80 e, nos primeiros anos do novo milênio, passou a interessar também aos pesquisadores da área da história. Este artigo, com olhar de historiador, procura contribuir para a renovação dos estudos sobre as escolas de samba.

\section{AS ESCOLAS DE SAMBA E OS MOVIMENTOS NEGROS}

A maior incidência de trabalhos sobre os movimentos negros no Brasil deixou os anos 60 como uma espécie de hiato na história da trajetória de organização e luta dos grupos e associações criadas no período. A ênfase maior foi destinada ao período final dos anos 70, no bojo do processo de anistia e abertura política do regime militar, a partir de 1974. A criação do Movimento Negro Unificado (MNU), no final da década, ganhou centralidade na versão sobre a ação engajada dos movimentos organizados na produção historiográfica sobre o tema.

As escolas de samba, associações culturais com grande importância nos anos 60 na cidade do Rio de Janeiro, eram visivelmente núcleos de negros e mulatos, que, pela via artística, demarcavam espaços para o que se convencionava chamar de cultura negra. Mesmo com essa nítida percepção de serem as agremiações associações recreativas e culturais de origem negra, as escolas de samba foram ignoradas na construção da trajetória dos movimentos negros na historiografia produzida até os dias atuais. ${ }^{1}$

Essa opção dos pesquisadores se deve ao esquecimento ou à percepção de que as agremiações não tinham legitimidade para representar o movimento negro? O que estavam apresentando as escolas cariocas nos anos 60 para não ser mencionadas ou tratadas como parte integrante dos movimentos militantes? Se outros grupos e associações, como o Teatro Experimental do Negro, a União dos Homens de Cor, o Grupo Brasiliana, entre outros, de natureza recreativa e cultu- 
ral figuram nas listas dos pesquisadores, não parece estranha a exclusão das escolas de samba nessa referida lista?

Ao considerar os enredos propostos e as letras dos sambas apresentados pelas agremiações nos anos 50 e 60 expressões da questão racial, é possível perceber que elas desempenharam papel relevante como instituições culturais de expressão da identidade cultural dos negros brasileiros.

Desde a década de 1940, podemos identificar representações do negro na história brasileira nos desfiles das escolas de samba. As menções ao poeta Castro Alves e a seu mais famoso poema "Navio Negreiro" já estavam presentes nos desfiles oficiais. Segundo a pesquisadora Edilene Matos (2001, p. 125-126), "não é só nas comemorações de datas especiais - sobretudo as de nascimento e morte do poeta - em preces, louvações e paródias que Castro Alves se faz vivo na voz do povo".

Em 1948, em desfile na Praça 11, no Rio de Janeiro, a Escola de Samba Império Serrano conquistou o título de campeã do carnaval daquele ano, com evoluções inusitadas e a introdução de novos instrumentos de percussão como frigideiras e pratos de metal. O ponto culminante da vibração popular foi o samba-enredo Antônio Castro Alves. Na voz de Avarese - Abimael Nascimento Álvares, o samba composto por Comprido e Moleque sacudiu a multidão sob o comando de Jorginho Pessanha e Jorge José da Silva (MATOS, 2001, p. 125).

E a pesquisadora prossegue ao comentar a utilização do poeta e seu poema como mote em outras agremiações. Mesmo sem explicitar as letras, o registro torna-se importante na compreensão de que esses enredos tinham conexão com a história dos negros, sobretudo em relação ao passado africano, à travessia Atlântica e à vida de escravidão no solo brasileiro.

Neste mesmo ano, uma outra escola de samba, do terceiro grupo, a Unidos de Vila Isabel, desfilou com o enredo, Navio Negreiro. O mesmo tema e o poema foram retomados pela Mocidade Independente de Padre Miguel, em 1956 e pela Acadêmicos do Salgueiro em 1957. A Escola Unidos de Vila Isabel insistiu em homenagear Castro Alves e conseguiu passar para o segundo grupo, em 1960, com o enredo O Poeta dos Escravos. Em 1967, a Unidos de Manguinhos desfilou com o tema Homenagem a Castro Alves. O poeta também foi citado em vários outros enredos (...) especificamente sobre a Bahia (MATOS, 2001, p. 126).

Ao longo dos anos 50, a temática afro-brasileira passou a ser mais explícita nas letras dos sambas-enredo. Segundo os historiadores Alberto Mussa e Luiz 
Antônio Simas (2010, p. 63), o Salgueiro "merece o título de pioneira na linhagem afro-brasileira", pois "logo no seu primeiro desfile, em 1954, a escola desceu com Romaria à Bahia". Esse samba, composto por Abelardo Silva, Eduardo de Oliveira e José Ernesto Aguiar, também foi apontado como pioneiro na temática afro-brasileira, pela historiadora Monique Augras (1998), por conta da inclusão, pela primeira vez nas escolas, de uma palavra de origem africana: candomblé. A historiadora, com intensidade ratificou esse pioneirismo, "a negritude é, no samba-enredo, uma invenção do Salgueiro" (p. 91).

Dentro do discurso que garante o "pioneirismo" do salgueirense, presente na maioria dos pesquisadores, um dos pontos que garantem essa posição é o fato de a escola ter "descoberto" para o grande público tantos personagens, sobretudo de origem negra e mulata. Um deles, o artista Antônio Francisco Lisboa, conhecido como Aleijadinho, tido como um dos exemplos dessas "descobertas" da escola, já havia sido citado em desfile de uma pequena agremiação da Baixada Fluminense, Cartolinhas de Caxias, $^{2}$ como atestou o historiador e pesquisador Luiz Antônio Simas.

Um dos sambas de enredo mais bonitos que conheço é o "Benfeitores do Universo" (acima), cantado em 1953 pela velha Cartolinhas de Caxias. Hélio Cabral foi o autor da obra-prima com a qual a escola desfilou no carnaval da Baixada Fluminense. Em meio a personagens como Santos Dumont, Pedro Américo, Aleijadinho, João Caetano, Rui Barbosa, Carlos Gomes, Castro Alves e José do Patrocínio, o samba da Cartolinhas exalta a figura maior do Dr. Oswaldo Cruz, louvado pelo sambista como o "mártir da ciência". O samba é bonito pacas, e a homenagem é justa. ${ }^{3}$

A letra do samba evidencia a menção ao artista mineiro, elogiando sua destreza e sua importância. Não temos outras informações sobre o desenvolvimento do enredo nem notícias sobre esse desfile, mas constata-se que, para os compositores da escola da Baixada Fluminense, Aleijadinho fazia parte de um grupo de brasileiros ilustres.

Acordem Benfeitores do universo / Que vou render tributo aos meus heróis / E nesta apoteose à grandeza / Eu peço a presença de todos vós / De todos vós / Antonio Francisco Lisboa / O maior vulto da arte colonial / Pedro Américo, emérito pintor / João Caetano, o nosso maior ator / Salve José do Patrocínio / O denodado baluarte nacional / Exaltemos Carlos Gomes / Orgulho da nossa terra / No cenário musical / Ruy Barbosa, símbolo da inteligência / Oswaldo Cruz, mártir da ciência / Santos Dumont, o pai da aviação / E Castro Alves, poeta da abolição / Acordem heróis ${ }^{4}$ 
Numa busca aos jornais em sua cobertura pré e pós-carnavalesca, algumas situações, completamente ignoradas no presente, estavam vivas e em movimento na preparação do carnaval das escolas de samba. Aleijadinho, citado acima, foi duplamente homenageado em 1961. Concomitante ao desfile do Salgueiro, a Aprendizes de Lucas escolheu o personagem como mote de seu enredo. Essa questão foi notícia nas páginas do Jornal do Brasil.

O artista Antônio Francisco Lisboa - Aleijadinho será motivo-enredo para duas escolas de samba no carnaval de 1961: Acadêmicos do Salgueiro, cuja formação já foi revelada pelo JORNAL DO BRASIL, e Aprendizes de Lucas, que tem também o seu carnaval aqui antecipado. O idealizador do enredo dos Aprendizes é o veterano carnavalesco e novo sambista João Moleque. A diferença entre as duas escolas de samba será somente no nome. Os Acadêmicos do Salgueiro desfilarão com No Tempo de Aleijadinho, enquanto os Aprendizes de Lucas apresentarão A Vida e a Obra de Antônio Francisco Lisboa. A vida do Aleijadinho será apresentada pelos Aprendizes de Lucas em várias fases, desde o seu batismo até a sua morte. Quanto às obras, serão apresentadas as mais famosas, inclusive em três das quatro carretas que desfilarão. Uma carreta representará a oficina do Aleijadinho: a outra Os profetas, uma das suas obras mais famosas; a terceira o seu sacrifício e a última será uma homenagem aos artistas atuais do Estado da Guanabara. Os figurinos, que são o ponto alto dos desfiles dos Aprendizes de Lucas, obedecerão ao critério da época do artista. $^{5}$

Por que a homenagem da escola de Lucas praticamente não foi comentada nos livros que narraram os desfiles dos anos 60 ? 0 desfile do Salgueiro teria ofuscado tanto assim a concorrente? O resultado final da escola, no desfile de 1961, ocupando as últimas colocações, contrastou com o vice-campeonato do Salgueiro. As posições desiguais e o fato de a escola Aprendizes de Lucas ter passado por um processo de fusão com a Unidos da Capela, em meados dos anos 60 , podem explicar esse processo de "esquecimento", que acabou cristalizando a versão de ser apenas o Salgueiro o responsável pelo resgate da história do artista mineiro.

Outro exemplo de pioneirismo discutível foi o enredo do Salgueiro sobre Dona Beija em 1968. Apontado por Haroldo Costa (1984, p. 174) como inédito, o enredo tinha sido apresentado por duas escolas do segundo grupo, dois anos antes. A escola Aprendizes da Gávea desenvolveu o enredo A Vida em Flor de D. Beja, e a Independentes do Leblon, desfilou com D. Beja, a Feiticeira de Araxá. ${ }^{6}$ 
Nenhuma das duas escolas alcançou boa colocação, mas é um dado interessante verificar que não uma, mas duas escolas trouxeram o mesmo enredo, que até então, pelo que pude constatar nesta pesquisa, não havia sido apresentado. ${ }^{7}$ Novamente o processo do esquecimento dos pesquisadores ocultou a ação das escolas do segundo grupo, num processo de apenas enxergar o que comprova a tese da ação pioneira e revolucionária da agremiação da Tijuca.

Retomando a discussão sobre a temática do negro, constatei que, na segunda metade dos anos 50 , as narrativas mais expressivas que predominaram nas letras dos sambas estavam centradas nas lembranças do passado de escravidão (MUSSA, SIMAS, 2010, p. 64) Os sentimentos mais retratados eram de dor e humilhação, por conta das punições e castigos físicos a que os escravos eram submetidos, quando desobedeciam às ordens dos seus senhores. O samba da Acadêmicos do Salgueiro em 1957, "Navio Negreiro", autoria dos compositores Djalma Sabiá e Armando Régis, é um exemplo dessa narrativa.

Apresentamos / páginas e memórias / que deram louvor e glórias / ao altruísta e defensor / tenaz da gente de cor / Castro Alves, que também se inspirou / e em versos retratou / o navio onde os negros / amontoados e acorrentados / em cativeiro no porão da embarcação / com a alma em farrapo de tanto mau-trato / vinham para a escravidão / Ô-ô-ô-ô-ô / No navio negreiro / o negro veio pro cativeiro / Finalmente uma lei / o tráfico aboliu / vieram outras leis / e a escravidão extinguiu / a liberdade surgiu / como o poeta previu / Ô-ô-ô-ô-ô / Acabou-se o navio negreiro / não há mais cativeiro. ${ }^{8}$

Outros exemplos significativos desse contexto de escravidão, desde a travessia até a vida nas senzalas das fazendas, são os sambas da Unidos da Tijuca. Em 1958, "Negro na Senzala", do compositor Darcy da Mangueira, embalou o desfile da agremiação, cujos componentes cantaram o samba que se referia aos maus-tratos e humilhações sofridos pelos negros escravizados, segmentados no espaço social que Ihes cabia nas fazendas, a senzala.

Nos idos tempos coloniais / no Brasil de escravo e senhor / o negro era transladado / e depois arrematado / pelo escravizador / e dessa época pra cá / sofrimento era demais, era demais / negro tinha que trabalhar / trabalhar até cair / no engenho de açúcar / na colheita de algodão / negro era castigado / pelo senhor do sertão / a casa-grande / requinte de grande fidalguia / mas sem o labor do negro / o senhor nada fazia / preta velha / ama do filho do senhor / negro na senzala / esquecia os momentos de dor / com lindas danças e cantorias / preto velho não pensava / em seus momentos de agonia. ${ }^{9}$ 
O cotidiano de sofrimento do negro escravizado, desde sua vinda do continente africano, era apresentado sem metáforas e de forma bastante direta. 0 escravo trabalhava em várias frentes produtivas e, como foi dito na letra do samba, trabalhava até cair. $O$ único momento de afastar as tristezas e lamentações de todo sofrimento era encontrado pela arte, em que o escravo "esquecia os momentos de dor/com lindas danças e cantorias". Dessa forma, segundo o samba, "o preto velho não pensava em seus momentos de agonia".

Outro ponto importante, destacado pelo samba era a função de ama de leite que muitas escravas desempenhavam, ocupando assim, temporariamente, um lugar no espaço social da elite, a casa-grande. O contraste era evidente, pois as crianças negras ficavam sem atenção, enquanto as mulheres negras escravas alimentavam os filhos da elite. A diferenciação dos lugares destinados às duas classes, escravos e senhores, era bastante delimitada, mas possibilitava uma pequena circulação, estabelecida na subserviência que os escravos tinham de prestar a seus donos.

Outro momento marcante da escola Unidos da Tijuca foi com o enredo Leilão de Escravos, em 1961, apresentando o samba composto pelos sambistas Mauro Affonso, Urgel de Castro e Cici. Novamente o mote da canção era o trabaIho associado ao sofrimento e às desigualdades encontradas entre os espaços da casa-grande e da senzala.

Quem dá mais, quem dá mais (bis) / Negro é forte, rapaz / Era assim / Apregoado em leilão (bis) / O negro que era trazido para a escravidão / Ao senhor era entregue / Para qualquer obrigação / Trabalhava no engenho da cana / Plantava café e colhia algodão / Enquanto isso / Na casa-grande, o feitor / Ouvia as ordens / De um ambicioso senhor / Ôôôô / Tenha pena de mim, meu senhor (bis) / Tenha por favor / E o negro trabalhava / De janeiro a janeiro / O chicote estalava / Deixando a marca do cativeiro / E na senzala / O contraste se fazia / Enquanto o negro apanhava / A mãe preta embalava / O filho branco do senhor que adormecia / Ôôôô / Tenha pena de mim, meu senhor (bis) / Tenha por favor. ${ }^{10}$

O samba de 1961 guardou semelhanças com o de $1958,{ }^{11}$ pois ambos tomaram como ponto inicial da narrativa a travessia atlântica, dando ênfase ao momento em que os senhores compravam seus escravos nos portos brasileiros. No samba "Leilão de Escravos", esse ponto inicial ganhou maior destaque. Na sequência, foram apresentados os principais produtos que eram cultivados. No samba de 1958, foram destacados a cana-de-açúcar e o algodão; já no samba de 1961, à cana e ao algodão foi acrescentado o café. Essa inclusão amplia o corte temporal 
da canção, pois o café foi cultivo mais ligado ao período imperial do que ao período colonial.

O trabalho extenuante dos escravos foi ressaltado nos dois sambas, "trabalhar até cair" (1958) e "de janeiro a janeiro" (1961). A violência física ficou, entretanto, mais explícita no samba "Leilão de Escravos" com a referência aos castigos corporais inseridos no cotidiano do trabalho, como em "O chicote estalava / Deixando a marca do cativeiro". Outro momento mais direto apresentado pelo samba de 1961 em relação à composição de 1958 foi o destaque dado à muIher negra escrava, ama de leite na casa-grande. Percebi que no samba de Mauro Affonso, Urgel de Castro e Cici, o contraste da situação ampliava o sentimento de injustiça e desigualdade, pois "Enquanto o negro apanhava / A mãe preta embalava / O filho branco do senhor que adormecia".

O tom de lamento e pedido de piedade ao senhor de engenho estabelece a semelhança dos dois sambas que, inseridos no contexto cultural da virada dos anos 50 para os 60, remetem ao momento em que algumas associações artísticas e políticas do movimento negro, como o Teatro Experimental do Negro (TEN) e a União dos Homens de Cor (UHC), tinham produzido frutos e promovido discussões sobre as desigualdades sociais entre negros e brancos na sociedade brasileira (PEREIRA, 2013, p. 123).

Os dois sambas da Unidos da Tijuca estavam diretamente relacionados aos debates, sobressaindo o sentido de denúncia dessas desigualdades, mesmo que as localizando no momento passado, da escravidão nos períodos colonial e do império. Não seriam esses enredos e seus sambas correspondentes peças de promoção do debate racial? Não seria a escola do morro do Borel, no bairro da Tijuca, Zona Norte da cidade do Rio de Janeiro uma associação artística cultural em sintonia com as demais associações dos movimentos negros no Brasil? Por que as escolas de samba foram excluídas dessa narrativa?

Uma possível resposta pode ser pensada com a análise do enredo apresentado pela Mocidade Independente de Padre Miguel no Carnaval de 1958. Sob o título "Apoteose ao Samba", composto por Toco e Cleber, o samba apresentava duas partes, aparentemente diversas:

Nas noites enluaradas / No tempo do cativeiro / Todos devem conhecer / A fama de carrasco / Do coronel Trigueiro / Mas existia um porém / É que o "seu" coronel, toda fúria perdia / Quando escutava no terreiro / Um preto velho amarrado no tronco / Que entoava sua melodia / Era o Samba, sim senhor / Entoado com sofrimento e dor / Neste ritmo cadenciado / Que pelo Brasil se propagou / Radiofonia, imprensa falada / Associação, departamento de turismo / 
Que com muito brilhantismo / Pelo nosso samba trabalhou / Confederação Brasileira / Lutou pelo mesmo ideal / Para que o samba se tornasse / O orgulho nacional. ${ }^{12}$

Na primeira parte, ressaltava-se o cotidiano de violência a que o escravo estava submetido, vencido, entretanto, pelo ritmo do samba, gestado na agonia e dor do pelourinho/tronco. A segunda parte procurava exaltar os meios de difusão a que o ritmo samba conseguiu se relacionar e foram fundamentais para sua expansão. $O$ elogio aos jornalistas, radialistas e funcionários do então Departamento de Turismo parecia ser forma de buscar aceitação e legitimidade para as agremiações. Essas estratégias de aproximação, via as boas relações, poderiam ser interpretadas pelas organizações mais radicais dos movimentos negros como ações subservientes, portanto descoladas do intuito central das organizações surgidas nos anos 40 e 50 ?

Segundo Antonio Sergio Guimarães (2013), em seu artigo sobre o pensamento de Abdias do Nascimento, até os anos 1950, as representações estavam bem alinhadas com a ideia do lamento (escravidão) e da democracia racial (integração étnica), muito embora uma variada gama de representações se estivesse estabelecendo, a partir de um constante debate e da circulação de ideias de pensadores, como Arthur Ramos, Roger Bastide, Florestan Fernandes, Edison Carneiro e do sociólogo Guerreiro Ramos, citados no artigo.

A busca da ancestralidade africana, religiosidade e visualidade das vestimentas, simbolizando as crenças e o olhar sobre o mundo, estava na ordem do dia das discussões, ganhando espaço entre os intelectuais que debatiam ou militavam nos diversos segmentos dos movimentos negros no Brasil. Esse processo teve como base os anos 50, quando a questão da negritude passou a ser incorporada à ideia de democracia racial, que parecia ser o pilar mestre da concepção da presença negra no país.

Nos anos 1950, Guerreiro Ramos e Abdias do Nascimento falarão ocasionalmente de raça negra; mas é a ideia de cultura negra, tal como utilizada pelos autores da negritude, que os influenciava mais. Não sem críticas e nunca integralmente, pois eles preferiram falar em cultura afro-brasileira, rechaçando o afrocentrismo e o pan-africanismo da negritude. Ao contrário, a negritude brasileira terá a característica peculiar de ser fusionada à democracia racial (GUIMARÃES, 2013, p. 161).

Citando um trecho do texto de Abdias para o jornal O Quilombo, uma das vertentes do TEN, Guimarães apontou a questão do momento difuso dos debates sobre o negro e seu espaço social no pensamento dos intelectuais que in- 
fluenciaram as diversas organizações dos movimentos negros pelo país, no início dos anos 1950.

No momento em que lançamos na vida nacional o mito da negritude, fazemos questão de proclamá-la com toda clareza. A negritude não é um fermento de ódio. Não é um cisma. É uma subjetividade. Uma vivência. Um elemento passional que se acha inserido nas categorias clássicas da sociedade brasileira e que as enriquece de substância humana. (...) A negritude, com seu sortilégio, sempre esteve presente nesta cultura, exuberante de entusiasmo, ingenuidade, paixão, sensualidade, mistério, embora só hoje por efeito de uma pressão universal esteja emergindo para a lúcida consciência de sua fisionomia" (O Quilombo, n. 10, jun.-jul. 1950, p. 11, apud GUIMARÃES, 2013, p.161-162)

Os sambas, apresentados até aqui, estavam, sem dúvida, dialogando com as discussões encetadas pelos intelectuais engajados na militância e na pesquisa sobre os negros brasileiros. A forma encontrada pelas agremiações não parece diferir tanto das resoluções estéticas e ideológicas dos textos do jornal O Quilombo ou das encenações realizadas pelo TEN. ${ }^{13}$

No desfile de 1964, a Estação Primeira de Mangueira apresentou Histórias de um Preto Velho. Esse enredo merece ter a letra de seu samba citado. Pouco lembrado pela bibliografia sobre as escolas de samba, dentro do quadro da presença negra, a composição parecia ser um manifesto. Os compositores da canção, Hélio Turco, Comprido e Pelado, buscaram sedimentar a figura do negro como um dos pilares da história brasileira e sua integração nos espaços sociais, sobretudo na cidade do Rio de Janeiro.

Era uma vez um preto velho / Que foi escravo / Retornando à senzala / Para historiar o seu passado / Chegando à velha Bahia / Já no cativeiro existia / Preto velho foi vendido / Menino a um senhor / Que amenizou a sua grande dor / Quando no céu a lua prateava / Que fascinação / Preto velho na senzala / Entoava uma canção / Ô... ô... ô... / Conseguiu tornar realidade / O seu ideal a liberdade / Vindo para o Rio de Janeiro / Onde o progresso despontava / Altaneiro / Foi personagem ocular / Da fidalguia singular / Terminando a história / Cansado da memória / Preto velho adormeceu / Mais o lamento de outrora / Que vamos cantar agora (bis) / Jamais se esqueceu / Ô... ô... ô.... ${ }^{14}$

As imagens poéticas inseridas na canção, como a relação do nascimento do ritmo samba a partir do lamento das senzalas, assemelhava-se com o samba da Mocidade Independente de Padre Miguel em 1958, já citado. Essa busca de 
uma cosmogonia para o samba, estava passando por novas abordagens. A filiação apresentada criava uma conexão entre a África, as senzalas, os terreiros e os morros cariocas.

A narrativa do negro escravo, com lamentos e humilhações, entrecruzavase com a ideia da integração entre as raças, pois a sorte do escravo, futuro preto velho, era ter sido comprado por um senhor "que amenizou a sua dor". Outro ponto importante na letra do samba é a importância da oralidade na transmissão de valores e das manifestações culturais. O final do samba, com a morte do preto velho procurou criar um momento onírico, descrito como os sonhos do personagem, metáfora para a passagem da vida para a morte, conquistando, assim, na eternidade, a integração, numa perspectiva cósmica, cujos lamentos haviam terminado, mas não seriam jamais esquecidos.

A história dos desfiles das escolas de samba tem várias lacunas que necessitam ser preenchidas. Um caso bastante interessante, dentro dessa temática, foi protagonizado pela pequena escola Tupy de Brás de Pina no Carnaval de 1959. Enquanto as demais agremiações desfilavam a Batalha de Tuiuti, Coroação de D. Pedro I, Brasil Panteão de Glórias, Brasil Holandês, a escola apresentou Memórias de um Preto Velho; no mesmo ano do início da "revolução" do Salgueiro, uma modesta escola apresentava um enredo, sem dúvidas, sobre a cultura do negro.

A descrição do desfile da agremiação na matéria do JB não nos permite vislumbrar detalhadamente o desenvolvimento do enredo, mas é bastante pertinente para ampliar a percepção de que a temática negra estava circulando pelos subúrbios e favelas da cidade e seria apresentada no desfile das escolas de samba.

11.20: Atrás do carro "abre-alas", pedindo passagem e saudando o povo e a imprensa, vem Jurema, a porta-bandeira, com lêdo, o mestre-sala. Seguem 500 sambistas, pastoras e baianas, apresentando o enredo concebido por Gilberto Andrade. É a Escola de Samba Tupi de Brás de Pina contando as Memórias de um preto veIho, que morreu antes de ter sido promulgada a Lei Áurea. A bateria é boa, o samba é vivo, as alegorias são simples, mas bonitas. A Escola tem o pavilhão azul e branco. A avenida está quase deserta. O asfalto queima, a Escola evolui como flores negras, mulatas e mamelucas, desabrochando do chão. São 12 horas e 13 minutos, quando termina o "ballet" fantástico. A Comissão Julgadora levanta-se para ir dormir. ${ }^{15}$

O livro do jornalista João Pimentel, Marcadas para viver, lançado em 2012, apresenta mais informações sobre esse desfile completamente ignorado pelos memorialistas do carnaval. Contando a saga de cinco pequenas escolas de samba 
do Rio de Janeiro, que tiveram destaque nas décadas de 1960 e 1970 e atualmente estão em grupos inferiores, o jornalista levantou, a partir de narrativas das personalidades das agremiações, as histórias de glória e tristezas que a memória do carnaval nem sempre destacou. Após narrar a história de Unidos do Jacarezinho, Em Cima da Hora, Unidos de Lucas e Vizinha Faladeira, João Pimentel (2012) iniciou a narrativa sobre a Tupy de Brás de Pina. O motivo dessa ordem parece que se deve ao fato de a escola do subúrbio carioca ter "enrolado"16 a bandeira.

Realmente, a Tupy já era grande quando a turma chegou da Zona Sul. Na estreia, no desfile na Avenida Presidente Antônio Carlos, dia 3 de março de 1957, terminou em segundo lugar no Grupo 2, com "Ordem e Progresso". No ano seguinte, entre as grandes na Avenida Rio Branco, conseguiu um honroso oitavo lugar com "Inconfidência Mineira". Mas, em 1959, a ousadia de assumir um enredo que fugia da história oficial do Brasil, "Memórias de um preto velho", derrubou a escola de volta para o Grupo 2 (PIMENTEL, 2012, p. 95).

Outro dado interessante é a foto estampada no início do livro (Imagem 15), retratando parte do desfile da escola em 1959. No canto esquerdo da foto vemos um pequeno carro alegórico com três bonecos de tamanho natural, representando um preto velho sentado num tronco de árvore e duas mulheres realizando trabalhos manuais. Ao fundo da pequena alegoria, uma representação de um barraco de pau a pique com telhado de palha. Atrás da alegoria, algumas muIheres e cerca de uma dúzia de homens trajando calças curtas e camisas de manga comprida, descalços; na cabeça dos homens chapéus, que lembram os utilizados pelos salineiros; as mulheres usam vestidos compridos, de mangas curtas e turbantes nas cabeças; pelo menos dois homens estão sem camisa; no meio da foto, aparece o casal de mestre-sala e porta-bandeira; ao fundo, uma ala, aparentemente com fantasias de nobres, com guarda-sóis como adereços.

Essa escola, conforme a matéria do JB, foi a última a se apresentar, já ao meio-dia da segunda-feira de carnaval, o que explica o porquê de sua apresentação ter sido relegada "ao limbo do esquecimento", acarretando seu "rebaixamento" como resultado final. Segundo a assertiva do jornalista João Pimentel a ousadia da agremiação em apresentar um tema fora do escopo usual foi um dos motivos da má colocação. Por que Memórias de um preto velho não está entre os enredos tidos como pioneiros na apresentação da cultura negra nas escolas de samba? Por que o desfile da Tupy de Brás de Pina ainda é ignorado por jornalistas e pesquisadores do carnaval carioca?

E o desfile do Salgueiro no mesmo ano, tido como início da "revolução estética e temática", teria sido mais contundente na questão da abordagem da cul- 
tura afro-brasileira? A julgar pela letra do samba-enredo "Viagem pitoresca e histórica ao Brasil”, apresentado pelo Salgueiro em 1959, composto por Djalma Sabiá e Duduca, não ficava muito explícita essa apropriação da temática negra.

Obras de vulto e encantos mil / Legou Debret / Às nossas belas-artes, ao Brasil / Pintou com genial saber / Para sua era reviver! / Foi na verdade um grande artista / Primaz documentarista / Do Brasil colonial / Tendo alcançado a galeria imortal / Retratou nativas maravilhas e coisas mil / Série de acontecimentos nacionais / Viajando através do Brasil... / Seu patrimônio histórico hoje nos traz / 0 tempo imperial / revelando o valor do pintor / Que exaltou a nossa vida nacional / Lá-lá-lá-lá-lá-lá. ${ }^{17}$

Nesse caso, o samba foi menos efetivo do que a visualidade proposta pelos artistas responsáveis pelo desfile do Salgueiro em 1959. As fantasias buscaram representar os negros nas diversas atividades desempenhadas, retratadas por Debret em suas aquarelas (Imagem 16).

Que elementos no enredo sobre Debret teriam destacado tanto o Salgueiro a ponto de essa menção ao desfile da Tupy de Brás de Pina ser ignorada por pesquisadores e memorialistas?

A agremiação do bairro de Brás de Pina encerrou os desfiles das escolas do primeiro grupo em 1959 e certamente foi assistida por componentes e dirigentes de outras agremiações, incluindo a Mangueira. Será que a narrativa adotada pela escola foi semelhante à do enredo mangueirense em 1964? Que pontos eram convergentes? Que abordagem foi dada ao personagem? Que período de sua vida foi cantado e representado?

Infelizmente, por ora, essas perguntas ficarão sem resposta, pois a letra do samba da Tupy de Brás de Pina do Carnaval de 1959 não foi encontrada. Em 1964, segundo pesquisa nos sites especializados, a escola voltou a apresentar o mesmo enredo, mas estava no segundo grupo, e a letra do samba não deve ter sido divulgada, o que dificultou ainda mais a sua localização.

O samba da Mangueira de 1964, "Histórias de um preto velho", não parecia estar muito distante das ideias dos movimentos negros. O samba denunciava a falsa inserção social e não mascarava a questão do racismo existente, mas, a partir de uma construção figurativa positiva dos negros, indicava a possibilidade de integração, sem conflitos ou confrontos diretos. Por outro lado, a base da democracia racial foi sofrendo, na virada dos anos 50 para os 60, uma inflexão, carregada de tensões, em que os intelectuais, como Abdias do Nascimento, Guerreiro Ramos, Roger Bastide e Solano Trindade, entre outros, procuravam articular a integração, sem perder o contato com o legado cultural africano nem perder 
a relação com os acontecimentos políticos no continente americano e na África contemporânea.

A ideia da democracia racial foi utilizada por diversos grupos, como uma bandeira de luta, ora amortecendo sentidos, ora aguçando novas ações. A ideia central era que a sociedade brasileira formava uma democracia racial. Esse mote central era apoiado por um grupo de intelectuais que perceberam as mudanças que estavam sendo processadas na vida política e social no Brasil e no mundo em geral, possibilitando uma ressignificação da ideia de democracia racial, como apontou Antonio Sergio Guimarães (2013, p. 161), na conclusão de seu artigo sobre Abdias do Nascimento.

O papel desempenhado pela Princesa Isabel no processo abolicionista foi um dos exemplos desse embate de visões. A maioria dos sambas apresentados pelas escolas e até aqui mencionados tratava o tema da abolição como uma consequência da ação do Estado. Uma pequena parte, sobretudo, a partir dos anos 60 , buscou apresentar o processo da abolição da escravidão como resultado da ação dos próprios negros.

A figura da Princesa Isabel estava no centro de um debate que ganharia contornos mais explícitos na década seguinte, quando os movimentos negros questionavam as comemorações do dia 13 de maio (Abolição da Escravidão) e incentivavam a adoção do dia 20 de novembro (morte de Zumbi) como data mais significativa para os movimentos negros no país. Esse debate também presente nas escolas foi apropriado e resultou num samba emblemático no Carnaval de 1968 da Unidos de Lucas.

A opção da agremiação foi contar a história da luta pela abolição destacando a figura da princesa Isabel como a "redentora", responsável pelo fim da escravidão no Brasil. Essa imagem foi bastante fortalecida pelo samba "Sublime Pergaminho", apresentado pela Unidos de Lucas no Carnaval de 1968. O samba dos compositores Carlinhos Madrugada, Zeca Melodia e Nilton Russo sobre a assinatura da Lei Áurea foi considerado um dos sambas mais bonitos de todos os tempos e merece uma citação literal. ${ }^{18}$ Quando o navio negreiro / Transportava negros africanos / Para o rincão brasileiro / Iludidos com quinquilharias / Os negros não sabiam / Que era apenas sedução / Pra serem armazenados / E vendidos como escravos / Na mais cruel traição / Formavam irmandades / Em grande união / Daí nasceram festejos / Que alimentavam o desejo / De libertação / Era grande o suplício / Pagavam com sacrifício / A insubordinação / E de repente uma lei surgiu / E os filhos dos escravos / Não seriam mais escravos no Brasil / Mais tarde raiou a liberdade / Para aque- 
les que completassem / Sessenta anos de idade / Ó sublime pergaminho / Libertação geral / A princesa chorou ao receber / A rosa de ouro papal / Uma chuva de flores cobriu o salão / E o negro jornalista / De joelhos beijou a sua mão / Uma voz na varanda do paço ecoou: / "Meu Deus, meu Deus / Está extinta a escravidão".19

A representação do negro humilde, sofrido e grato pela abolição construiu a imagem da Princesa Isabel como "redentora". O samba, emblemático no carnaval carioca, tendo a abolição como mote, não ressaltou a luta dos negros e a narrativa do processo da abolição; seguia os textos dos livros didáticos, ao pontuar as agruras da escravidão e as leis que foram sendo implantada na segunda metade do século XIX, culminando com a assinatura da Lei Áurea, pelas mãos da Princesa Isabel. $O$ samba se alinhou às narrativas de caráter festivo, sem discussões sobre a questão da futura inserção social dos negros na cidadania brasileira.

Sambas como o da Estação Primeira de Mangueira em 1960, do Salgueiro em 1960, da Unidos da Tijuca em 1961, da Em Cima da Hora no Carnaval de 1969, entre outros aqui citados demonstram que a narrativa da abolição passou por um processo de transformação. Nesses sambas, o processo que desencadeou a libertação dos escravos apareceu como um caminho natural das lutas dos próprios negros e não tanto a intervenção direta do Estado, na figura da Princesa Isabel, no dia 13 de maio de 1888.

Essas contraposições acompanharam por muito tempo o debate das diversas tendências dos movimentos negros no Brasil. Retratar a vida de sofrimento e dor dos escravos no período colonial e no Império brasileiro e apresentar as danças, festas e ritmos afro-brasileiros pareciam estar entre as principais representações dos negros nos desfiles das escolas de samba. Antagonismos que dialogavam entre si visando à integração e aceitação do negro na sociedade, a partir da postura humilde de um grupo que vivenciou na carne todas as humilhações e privações de direitos. Esse parecia ser o mote das apresentações das agremiações do carnaval carioca quando apresentavam enredos sobre o negro, mas não o único.

\section{CONSIDEREÇÕES FINAIS}

As escolas de samba foram associações que se consolidaram no cenário cultural brasileiro. Seus enredos e sambas divulgados para todo o país por meio da imprensa escrita e transmitidos pelas emissoras de televisão, em expansão na década de 1960, revelaram a importância das escolas e o poder de emissão de discursos. 
Os temas negros sempre estiveram presentes e, mesmo quando o enredo apresentava um tema aparentemente calcado na história oficial, era uma versão construída na chave da narrativa da cultura popular. As escolas de samba ajudaram a construir uma versão da história do negro no Brasil e, mesmo ignoradas pela historiografia dos movimentos negros, foram importantes emissoras de reflexões sobre a situação social, econômica e política dos homens e mulheres negros no país.

\section{NOTAS}

1 Sobre os anos 1970 podemos encontrar alguns poucos exemplos, como a tese de Gabriela Buscaccio sobre a Grannes Quilombo, criada em 1976, ou parcas menções no livro de Amílcar Pereira (2013, p. 239). As referências são rasas e incipientes, como no caso citado por Pereira, da articulação de grupos culturais na periferia de São Paulo, em torno das Escolas de samba Nenê de Vila Matilde e Vai-Vai.

20 próprio pesquisador assim explicou sobre a agremiação de Caxias: A Cartolinha de Caxias, para quem não sabe, uniu-se em 1972 às escolas União do Centenário, Capricho do Centenário e União da Vila São Luís para formar o GRES Grande Rio - agremiação que, em 1988, foi incorporada pela Acadêmicos de Duque de Caxias no processo que deu origem ao GRES Acadêmicos do Grande Rio. Artigo "Mártir da Ciência", no site Ouro de Tolo, postado em 14/3/2013. in http://www.pedromigao.com.br/ourodetolo/2013/03/historias-brasileiras-o-martir-da-ciencia/. Pesquisado em 25/04/2013.

3 www.pedromigao.com.br/ourodetolo/2013/03/historias-brasileiras, pesquisado em 19/03/2013.

40 pesquisador Luiz Antonio Simas me enviou a letra pelas redes sociais, após divulgar o artigo que havia publicado sobre o tema.

5 Jornal do Brasil, 18/1/61, p. 4, Caderno B.

6 As duas agremiações ficaram em quarto e quinto lugares, respectivamente.

7 Jornal do Brasil, 24/2/66, p.9, Caderno B.

8 www.vagalume.com.br, pesquisado em 5/6/2013.

9 www.vagalume.com.br, pesquisado em 10/01/2012.

10 www.video.sonicomusica.com/unidos-da-tijuca-1961-leilo-de-escravos, pesquisado em 23/02/2013.

11 Os historiadores Luiz Antônio Simas e Alberto Mussa (2010) apontam que os dois sambas podem ter sido do mesmo ano (1961), do enredo Casa-Grande e Senzala, e o que foi citado como de 1958 teria sido o samba eliminado na fase final da disputa pela escolha do samba oficial.

12www.academiadosamba.com.br/memoriasamba/artigos/artigo-262.htm, pesquisado em 11/01/2012. 
13 Sobre a importância do TEN, dos espetáculos realizados e das ações sociais de cunho racial empreendidas, ver Nascimento, Abdias do. Teatro experimental do negro: trajetória e reflexões. Revista Estudos Avançados, v.18, n.50. São Paulo, jan. 2004 e Da Silva, Júlio Cláudio. Das cores no teatro: histórias do tempo da fundação do Teatro Experimental do Negro nos relatos de Ruth de Souza:(1940) in www.fiocruz.br/ehosudeste/templates/htm/viiencontro/textosIntegralpdf, pesquisado em 22/3/2012.

14 www.vagalume.com.br, pesquisado em 13/02/2013.

15 Jornal do Brasil, 15/02/59, p. 15.

16 No jargão carnavalesco significa o encerramento das atividades da agremiação, que ocorreu em 1997, quando realizou seu último desfile.

17 www.multishow.globo.com/musica/gres-academicos-do-salgueiro/samba-enredo-1959, pesquisado em 21/01/2011.

18 Dos sambas que versam sobre a história dos escravos no Brasil, "Sublime Pergaminho", apresentado pela Unidos de Lucas em 1968, talvez seja a mais completa e mais bela obra. O samba de Nilton Russo, Zeca Melodia e Carlinhos Madrugada descreve com certa tristeza o período do tráfico intenso dos negros da África para cá e explode de alegria quando fala das leis que culminaram na Lei Áurea de 1888, que deu fim à escravidão no Brasil. Disponível em www.bancadadosamba.wordpress.com/grandes-enredos/sublime-pergaminho-unidos-de-lucas-1968, pesquisado em 16/01/2014.

19 www.vagalume.com.br, pesquisado em 5/6/2013.

\section{REFERÊNCIAS BIBLIOGRÁFICAS}

AUGRAS, Monique. O Brasil do samba-enredo. 1 ed. Rio de Janeiro: FGV, 1998.

COSTA, Haroldo. Salgueiro: academia do samba. Rio de Janeiro: Record, 1984.

GUIMARÃES, Antonio Sergio Alfredo. Resistência e revolta nos anos 1960: Abdias do Nascimento. Revista da USP, n. 68, 2013.

MATOS, Edilene. Castro Alves, imagens fragmentadas de um mito. São Paulo: PUC, 2001.

MUSSA, Alberto; SIMAS, Luiz Antonio. Samba de enredo - história e arte. Rio de Janeiro: Civilização Brasileira, 2010.

PEREIRA, Almicar Araújo. O mundo negro: relações raciais e a constituição do movimento negro contemporâneo no Brasil. Rio de Janeiro: Pallas/Faperj, 2013.

PIMENTEL, João. Marcadas para viver - a luta de cinco escolas. Rio de Janeiro: Verso Brasil, 2012.

Guilherme José Motta Faria é graduado em história (UERJ), mestre em história política (UERJ) e doutor em história social (UFF).

Recebido em: 13/09/2014

Aceito em: 21/10/2014 